\title{
Seroprevalence of Human T-lymphotropic virus type- 1 and -2 infections among first-time United States Blood Donors 2000-2009
}

\author{
Yun Brenda Chang ${ }^{1,2}$, Zhanna Kaidarova ${ }^{2}$, Daniel Hindes ${ }^{2}$, Marjorie Bravo ${ }^{3}$, Nancy Kiely ${ }^{3}$, Hany Kamel ${ }^{3}$, \\ Denise Dubay ${ }^{3}$, Barbara Hoose ${ }^{3}$, Edward L Murphy, $4,2^{*}$ \\ From 16th International Conference on Human Retroviruses: HTLV and Related Viruses \\ Montreal, Canada. 26-30 June 2013
}

\section{Background}

Human T-lymphotropic virus types 1 and 2 (HTLV-1 and -2 ) are prevalent at low-level among United States blood donors, but recent data on their prevalence is lacking.

\section{Methods}

Data on all first-time blood donors in a large network of United States blood centers was examined during the period 2000-2009. Anti-HTLV-1 and -2 was measured by enzyme immunoassay (EIA) screening with type-specific confirmation by immunofluorescence or RIBA. Prevalence and odds ratios (OR) and 95\% confidence intervals (CI) for associations with demographic characteristics were assessed using multivariable logistic regression.

\section{Results}

Among 2,047,740 first-time donors, 104 donors were seropositive for HTLV-I (prevalence 5.1 (95\% CI: 4.1 - 6.1) per 100,000) and 300 donors were seropositive for HTLV-2 infection (prevalence 14.7 (95\% CI 13.0 - 16.3) per 100,000). Prevalence was lower than reported in the 1990's but stable from 2000 to 2009. HTLV-1 seropositivity was associated with female sex $(\mathrm{OR}=1.56,95 \% \mathrm{CI}$ 1.05-2.32); older age; and Black ( $I R=25.29,9 \%$ CI 13.14$48.68)$ and Asian (OR $=21.43,95 \%$ CI 10.31-44.53) race/ ethnicity. HTLV-2 seropositivity was associated with female sex $(\mathrm{OR}=2.13,95 \%$ CI 1.67-2.73); older age; and non-white race/ethnicity; residence in the Western $(\mathrm{OR}=4.12$, 95\% CI 2.16-7.82) and Southwestern

${ }^{4}$ Departments of Laboratory Medicine and Epidemiology/Biostatistics,

University of California San Francisco, San Francisco, CA, USA

Full list of author information is available at the end of the article
(OR=2.47, 95\% CI 1.28-4.78; both vs. Northern) U.S.; and lower educational level.

\section{Conclusions}

HTLV-1 and -2 prevalences among U.S. blood donors declined since the early 1990's but were stable since 2000. Higher prevalence of HTLV-2 in the West and Southwest may be attributed to endemic foci among Amerindians.

\section{Authors' details}

'Department of Biostatistics, Columbia University, New York, NY, USA. ${ }^{2}$ Blood Systems Research Institute, San Francisco, CA, USA. ${ }^{3}$ Blood Systems, Inc., Scottsdale, AZ, USA. ${ }^{4}$ Departments of Laboratory Medicine and Epidemiology/Biostatistics, University of California San Francisco, San Francisco, CA, USA.

Published: 7 January 2014

\section{doi:10.1186/1742-4690-11-S1-P61}

Cite this article as: Chang et al: Seroprevalence of Human Tlymphotropic virus type- 1 and -2 infections among first-time United States Blood Donors 2000-2009. Retrovirology 2014 11(Suppl 1):P61.

\section{Submit your next manuscript to BioMed Central} and take full advantage of:

- Convenient online submission

- Thorough peer review

- No space constraints or color figure charges

- Immediate publication on acceptance

- Inclusion in PubMed, CAS, Scopus and Google Scholar

- Research which is freely available for redistribution 